\title{
Low-Threshold Transient Calcium Current in Rat Hippocampal Lacunosum-Moleculare Interneurons: Kinetics and Modulation by Neurotransmitters
}

\author{
Douglas D. Fraser and Brian A. MacVicar \\ Neuroscience Research Group, The University of Calgary, Calgary, Alberta, Canada T2N 4N1
}

Interneurons from the CA1 lacunosum-moleculare (L-M) region were isolated by trypsin-hyaluronidase treatment and mechanical trituration of the L-M. Interneurons isolated in this manner were multipolar with several dendritic processes and could be distinguished from CA1 pyramidal neurons. The properties of a low-threshold transient (LTT) $\mathrm{Ca}^{2+}$ current were investigated using whole-cell voltage-clamp techniques. The activation threshold of the LTT $\mathrm{Ca}^{2+}$ current was $-60 \mathrm{mV}$, and the peak current, $100 \pm 9 \mathrm{pA}$ (mean $\pm \mathrm{SEM}$; $n=15$ ), was observed at $-30 \mathrm{mV}^{-\mathrm{Ca}^{2+}}$ was the predominant charge carrier because the current was not affected by tetrodotoxin and was abolished in $\mathrm{Ca}^{2+}$-free external solution. Steady state inactivation was observed when the holding potential was positive to $-100 \mathrm{mV}$, and the current was halfinactivated at $-84 \mathrm{mV}$. Complete inactivation occurred at a holding potential of $-60 \mathrm{mV}$. The time-to-peak of the current was highly voltage dependent and ranged from $10 \mathrm{msec}$ at $-60 \mathrm{mV}$ to $4 \mathrm{msec}$ at $0 \mathrm{mV}$. The time constant of inactivation was also voltage dependent and ranged from $27 \mathrm{msec}$ at $-60 \mathrm{mV}$ to $12 \mathrm{msec}$ at $>-30 \mathrm{mV}$. Recovery from inactivation to $90 \%$ of maximum current occurred within $200 \mathrm{msec}$.

$L-M$ interneurons receive synaptic inputs from the septum that release $\mathrm{ACh}$ or GABA and from the raphe nuclei that release 5-HT. Carbachol, a nonhydrolyzable cholinergic agonist, and 5-HT quickly and reversibly increased the amplitude of the LTT $\mathrm{Ca}^{2+}$ current. Carbachol's actions were blocked by atropine, indicating that this effect was mediated by muscarinic receptors. The actions of 5-HT were blocked by spiperone, a serotonergic antagonist. Baclofen, which activates $\mathrm{GABA}_{\mathrm{B}}$ receptors, reversibly depressed $\mathrm{LTT} \mathrm{Ca}^{2+}$ currents. Cholinergic inputs from the septum and serotonergic inputs from the raphe nuclei are both believed to play a role in generating theta rhythm $(4-10 \mathrm{~Hz})$ in the hippocampal EEG. LTT $\mathrm{Ca}^{2+}$ currents have been shown to induce rhythmic bursting at theta frequencies in other cell types. This work suggests that muscarinic and serotonergic enhancement of LTT $\mathrm{Ca}^{2+}$ currents in L-M interneurons could be responsible for generating the theta rhythm in the hippocampus. GABAergic inputs may play a role in terminating the bursting.

\footnotetext{
Received Jan. 8, 1991; revised Apr. 17, 1991; accepted Apr. 22, 1991.

We thank Dr. Q. Pittman, Dr. S. Barnes, and Dr. R. Clark for comments on the manuscript and Dr. M. Walsh for discussion of G-proteins. This work was supported by the Medical Research Council (MRC) Canada. B.A.M. is an Alberta Heritage Foundation for Medical Research Scholar and an MRC Scientist.

Correspondence should be addressed to Brian A. MacVicar at the above address. Copyright (C) 1991 Society for Neuroscience 0270-6474/91/112812-09\$03.00/0
}

Low-threshold $\mathrm{Ca}^{21}$ spikes have been observed in vertebrate neurons from several brain regions, including the inferior olive (Llinas and Yarom, 1981), thalamus (Jahnsen and Llinas, 1984a,b), medial septum (Alvarez De Toledo and Lopez-Barneo, 1988), neocortex (Friedman and Gutnick, 1987), spinal cord (Murase and Randic, 1983), deep cerebellar nuclei (Llinas and Muhlethaler, 1988), pars intermedia (Williams et al., 1990), and lateral habenula (Wilcox et al., 1988). A low-threshold transient (LTT) $\mathrm{Ca}^{2+}$ current, first described in chick and rat dorsal root ganglion (Carbonc and Lux, 1984a,b), has been shown to be distinct from the high-threshold $\mathrm{Ca}^{2+}$ currents and has been termed t-type (Nowycky et al., 1985; Fox et al., 1987a,b). Voltage-clamp analysis of acutely dissociated thalamic and lateral geniculate neurons has also indicated that the LTT Ca ${ }^{2+}$ current underlies the low-threshold $\mathrm{Ca}^{2+}$ spike (Coulter et al., 1989; Hernandez-Cruz and Pape, 1989; Suzuki and Rogawski, 1989). The presence of low-threshold $\mathrm{Ca}^{2+}$ spikes imparts the possibility of rhythmic burst discharge patterns in neurons (Llinas, 1988). In the thalamus, hyperpolarizing inputs deinactivate the low-threshold $\mathrm{Ca}^{2+}$ spike and allow oscillations of membrane potential that occur at approximately $10 \mathrm{~Hz}$ (Deschenes et al., 1984; Jahnsen and Llinas, 1984b; Llinas, 1988). Rhythmic bursting at approximately $10 \mathrm{~Hz}$ due to low-threshold $\mathrm{Ca}^{2+}$ spikes has also been observed in lateral habenula neurons (Wilcox et al., 1988). Propagation of low-threshold $\mathrm{Ca}^{2+}$ spikes between clectrotonically coupled cclls could underlic the synchronous rhythmic oscillations of neurons in the inferior olive (Llinas and Yarom, 1986).

Whole-cell voltage-clamp recordings from cultured (Ozawa et al., 1989) and immature hippocampal neurons (Yaari et al., 1987) have revealed LTT $\mathrm{Ca}^{2+}$ currents. Recordings from isolated pyramidal neurons have generally not revealed LTT $\mathrm{Ca}^{2+}$ currents (Kay and Wong, 1987), although a subpopulation of pyramidal neurons may express this channel (Takahashi et al., 1989; Fisher et al., 1990). Intracellular recordings from interneurons in the lacunosum-moleculare (L-M) area of the CAl region suggested that these cells may have low-threshold $\mathrm{Ca}^{2+}$ spikes (Lacaille and Schwartzkroin, 1988a,b). Burst discharges were only observed when cells were hyperpolarized, a characteristic indicative of low-threshold $\mathrm{Ca}^{2+}$ spikes (e.g., Jahnsen and Llinas, 1984a,b). In contrast, basket cell interneurons of the stratum pyramidale and interneurons in the strata oriens-alveus do not have any indication of low-threshold $\mathrm{Ca}^{2+}$ spikes (Lacaille et al., 19.89; Lacaille and Williams, 1990).

The presence of low-threshold $\mathrm{Ca}^{2+}$ spikes in $\mathrm{L}-\mathrm{M}$ interneurons may be important in explaining the generation of rhythmic activity such as theta, which can be induced by muscarinic stimulation in the isolated hippocampal slice (MacVicar and 
Tse, 1989; Tse and MacVicar, 1989). Theta rhythm is a naturally occurring rhythm, (4-10 Hz) of the hippocampal EEG that can be observed in the conscious animal (Bland, 1986). This is within the bursting frequency observed in cells with prominent lowthreshold $\mathrm{Ca}^{2+}$ spikes. Synaptic inputs from the septum and serotonergic inputs from the raphe nuclei, which are believed to be the synaptic pathways that generate theta rhythms, have becn shown to synapsc on L-M interneurons (Freund and Antal, 1988; Freund et al., 1990). It has been suggested that phasic activity in septal cholinergic inputs could rhythmically drive hippocampal interneurons, which would then rhythmically inhibit pyramidal neurons (Stewart and Fox, 1990). We have investigated the possibility that these synaptically released transmitters enhance LTT $\mathrm{Ca}^{2+}$ currents in L-M interneurons, which could modulate endogenous bursting activity in these cells. To promote this study, we have developed a method for acutely isolating L-M interneurons for two reasons: (1) whole-cell voltage clamp of acutely isolated cells facilitates the rigorous isolation and identification of an ion current, and (2) the sparse distribution of L-M interneurons means that it is very difficult to obtain intracellular recordings reliably from these cells in the in vitro brain slice. In the present article, results from wholecell voltage-clamp experiments identify and describe the kinetic properties of $\mathrm{LTT} \mathrm{Ca}^{2+}$ currents in L-M interneurons. We also demonstrate enhancement of LTT $\mathrm{Ca}^{2+}$ currents by muscarinic and serotonergic activation and depression by GABAergic activation.

Some of this work has been presented in abstract form (Fraser and MacVicar, 1990).

\section{Materials and Methods}

Acute dissociation. Experiments were performed on hippocampal interneurons acutely isolated from the L-M utilizing a revised method of Kay and Wong (1986). Hippocampal slices $(500 \mu \mathrm{m})$ were obtained from male Sprague-Dawley rats (postnatal, 3-4 weeks old). The slices were incubated for $1 \mathrm{hr}$ in artificial cerebrospinal fluid (aCSF) containing (in mM) $124 \mathrm{NaCl}, 5 \mathrm{KCl}, 1.3 \mathrm{MgCl}_{2}, 2 \mathrm{CaCl}_{2}, 26 \mathrm{NaHCO}_{3}$, and 10 D-glucose ( $\mathrm{pH} 7.35 ; \sim 280 \mathrm{mOsm})$ aerated with $95 \% \mathrm{O}_{2} / 5 \% \mathrm{CO}_{2}$ at $21^{\circ} \mathrm{C}$. Slices were then transferred to a spinner flask (Bellco Glass Corp.) with a magnetic stirrer filled with $30 \mathrm{ml}$ of low-Ca ${ }^{2+}$ aCSF at $35^{\circ} \mathrm{C}$ containing (in mM) $124 \mathrm{NaCl}, 5 \mathrm{KCl}, 3.2 \mathrm{MgCl}_{2}, 0.1 \mathrm{CaCl}_{2}, 26 \mathrm{NaHCO}_{3}$, and 10 D-glucose; (pH 7.35; $280 \mathrm{mOsm}$ ), to which $1 \mathrm{~mm}$ kynurenic acid, $40 \mathrm{mg}$ of trypsin $(9000 \mathrm{U} / \mathrm{mg})$, and $20 \mathrm{mg}$ of hyaluronidase $(1500$ $\mathrm{U} / \mathrm{mg}$ ) were added. The slices were stirred at a rate sufficient to buoy them up and $95 \% \mathrm{O}_{2} / 5 \% \mathrm{CO}_{2}$ was introduced continuously. After 90 min slices were transferred to normal aCSF at $21^{\circ} \mathrm{C}$ until they were triturated. A slice was then transferred to HEPES-buffered Dulbeccos Modified Earls Medium (DMEM) containing $0.1 \mathrm{~mm}$ leupeptin. The $\mathrm{L}-\mathrm{M}$ was isolated with razor cuts under a dissecting microscope, transferred to a test tube containing $1 \mathrm{ml}$ of the modified DMEM, and dispersed by trituration with fire-polished Pasteur pipettes. The whole solution was then transferred to the recording perfusion chamber mounted on an inverted microscope (IM-35, Zeiss).

Cell perfusion. The interneurons were allowed to settle on a poly-Llysine coated coverslip for $10 \mathrm{~min}$ before the DMEM was replaced by superfusion of control aCSF $\left(21^{\circ} \mathrm{C}\right)$ containing sucrose $(40 \mathrm{~mm})$, tetrodotoxin (TTX; $1.0 \mu \mathrm{M})$, 4-aminopyridine (1 mM), and tetraethylammonium (10 mM) (pII 7.35; $2320 \mathrm{mOsm})$. The recording solution was aerated with $95 \% \mathrm{O}_{2} / 5 \% \mathrm{CO}_{2}$, and the rate of superfusion was adjusted to allow complete exchange of chamber solution within $60 \mathrm{sec}$. Highresistance seals ( $>2 \mathrm{G} \Omega$ ) were obtained from selected interneurons, the membrane was ruptured with negative pressure, and the cell contents were exchanged with the pipette-filling solution (in $\mathrm{mM}$ ): $120 \mathrm{CsF}, 15$ HEPES, 10 EGTA, 2 Mg-ATP, and 2 TEA-acetate; (pH 7.2; 280 mOsm). Experiments began several minutes after breakthrough, once the LTT $\mathrm{Ca}^{2+}$ current was isolated and the holding current was stable.

Electrophysiological recording. Patch electrodes were pulled from 1.0 mm o.d. thin-walled glass (1B 100F, World Precision Instruments) in two stages on a Narishige puller (PP-83). Electrodes were filled with the intracellular solution (described above) and had a tip resistance of 5$10 \mathrm{M} \Omega$ when tested in recording solution. A $7.5 \mathrm{mV}$ liquid-junction potential was measurcd between the clectrode and bath solution; however, voltage command levels were not compensated (thus, command potentials were shifted $7.5 \mathrm{mV}$ in the positive voltage direction). Current recordings were obtained using a single-electrode voltage-clamp amplifier (Axopatch-1A) and were filtered at $5 \mathrm{KHz}$. Compensation circuitry was used to minimize potential series resistance errors and could compensate $60-80 \%$ of the series resistance. Data were digitized and analyzed using pCLAMP software (Axon Instruments). Leak and capacitative currents were eliminated by subtracting currents from a holding potential of $-60 \mathrm{mV}$ (where the LTT Ca ${ }^{2+}$ current was inactivated) from currents obtained at a holding potential of $-100 \mathrm{mV}$ (where inactivation was minimal).

Materials. All inorganic salts were purchased from Fisher. Chemicals utilized were trypsin (Sigma, T-1005), hyaluronidase (Sigma, H-1254), kynurenic acid (Sigma, K-3375), leupeptin (Sigma, L-2884), tetrodotoxin (Sigma, T-8024), 4-aminopyridine (Sigma, A-0152), carbachol (CCH; Sigma, C-4382), atropine (Sigma, A-0257), 5-hydroxytryptamine (5-HT; Sigma, H-5755), spiperone (Sigma, S-7395), and baclofen (CIBAGeigy). All chemicals were added hyperosmotically to the recording solution from concentrated stocks.

\section{Results}

Dissociation of $L-M$ cells

L-M interneurons had a diverse morphology after dissociation with typical examples shown in Figure 1. The cells were easily recognized, and their morphology was very similar to that observed when L-M cells were stained by intracellular injection of Lucifer yellow and HRP (Misgeld and Frotscher, 1986; Kawaguchi and Hama, 1987; Kunkel et al., 1988; Lacaille and Schwartzkroin, 1988a). Most cells were fusiform, being multipolar with several primary dendritic branches still intact. Cell body size ranged from 15 to $20 \mu \mathrm{m}$ in diameter. The two other main cell types in the CA1 hippocampal region are astrocytes and $\mathrm{C} \Lambda 1$ pyramidal cells. Astrocytcs wcrc casily discerned by their smaller cell bodies $(10-12 \mu \mathrm{m})$ and numerous processes (S. Duffy et al., 1991). CAl pyramidal cells were observed only when the whole $\mathrm{CA} 1$ region was dissociated. Their morphology was different in that they typically had a pyramidal cell body and one apical dendritic process left after dissociation (Kay and Wong, 1986, 1987). Therefore, the main criteria that the cells voltage clamped in this study were indeed L-M interneurons were that (1) only the L-M region was dissociated and (2) the morphologies of dissociated interneurons were distinct from pyramidal cells and were similar to previous reports of their morphology revealed by injections of intracellular markers.

\section{LTT Ca $\mathrm{Ca}^{2+}$ currents}

These experiments were designed to examine the presence of LTT $\mathrm{Ca}^{2+}$ currents in L-M interneurons. The electrode contained $\mathrm{Cs}^{+}$to block $\mathrm{K}^{+}$currents and $\mathrm{F}^{-}$, which has been shown to suppress high-threshold $\mathrm{Ca}^{2+}$ currents (Kay et al., 1986). Whole-cell voltage-clamp recordings were obtained from $>200$ cells, but only 68 met the criteria for inclusion in this study ( $<40 \mathrm{pA}$ holding current at $-100 \mathrm{mV}$ holding potential). Input resistance was measured in a smaller number of these cells and was $2.68 \pm 0.36 \mathrm{G} \Omega$ (mean $\pm \mathrm{SEM} ; n=10$ ). All cells that were voltage-clamped from the L-M region exhibited a pronounced inward current that was greater than $2 \mathrm{nA}$ in control solution. This inward current was totally blocked by TTX $(0.5-1 \mu \mathrm{M})$ and was most likely a voltage-activated sodium current. After the sodium current was blocked with TTX, a transient inward current was observed in all cells $(n=68)$, including the other cells 

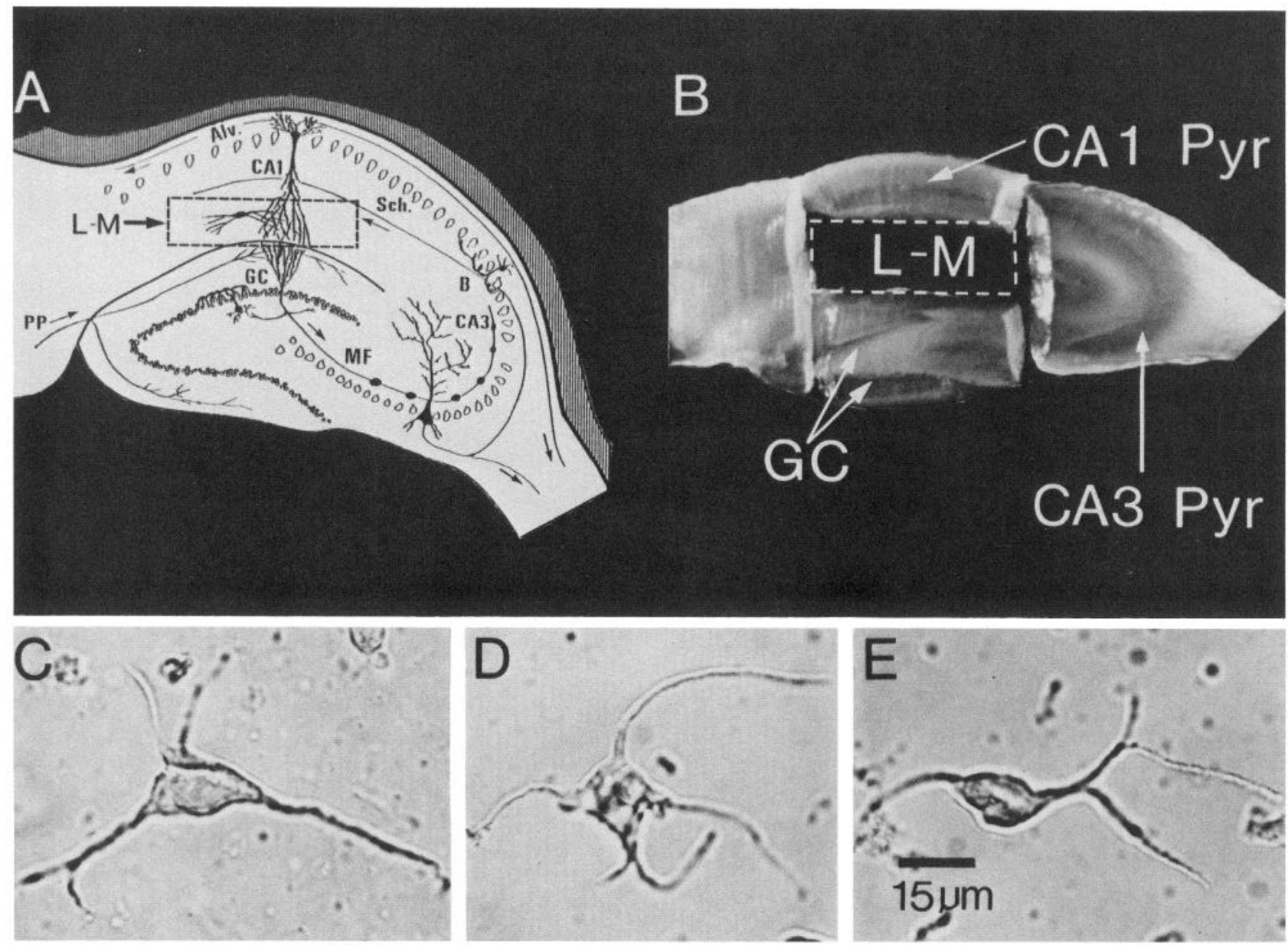

Figure 1. Photomicrographs of acutely dissociated interneurons from the L-M region. $A$, Schematic of the hippocampal slice showing the L-M region from which the interneurons were obtained. $B$, Photomicrograph of the hippocampal slice after the $\mathrm{L}-\mathrm{M}$ region was dissected free using four cuts with a scalpel. The hippocampal slice was reassembled for this photomicrograph to illustrate the dissection. The slice was transilluminated during the dissection. The L-M region was then mechanically triturated to produce the cells illustrated in $C-E$. L-M interneurons were recognized by their fusiform cell body. They always had multiple dendritic processes. They never had one single apical dendrite as is characteristic of CA1 pyramidal cells. $B$, basket cell; $G C$, granule cell; $P P$, perforant path; $S c h$, Schafer collaterals. $P y r$, pyramidal cell layer; $A l v$, alveus; $M F$, mossy fibers.

( $>200)$ that had high or unstable holding currents. This inward current typically activated at $-60 \mathrm{mV}$ with a peak amplitude of $100 \pm 9 \mathrm{pA}( \pm \mathrm{SEM} ; n=15)$ at $-30 \mathrm{mV}$ (Fig. 2). The current was totally inactivated at a holding potential of $-60 \mathrm{mV}$. Highthreshold $\mathrm{Ca}^{2+}$ currents were sometimes observed in these cells immediately following rupture of the membrane. However, the high-threshold $\mathrm{Ca}^{2+}$ current quickly deteriorated when pipettes contained $\mathrm{F}^{-}$. Extracellular $\mathrm{Cd}^{2+}(<25 \mu \mathrm{M})$ totally blocked any remaining high-threshold $\mathrm{Ca}^{2+}$ currents without altering the LTT $\mathrm{Ca}^{2+}$ currents.

$\mathrm{Ca}^{2+}$ appeared to be the major charge carrier for the inward current. Figure 3 shows the alteration in inward current that was observed when external $\mathrm{Ca}^{2+}$ was reduced. A decrease in extracellular $\mathrm{Ca}^{2+}$ from 2 to $0.1 \mathrm{~mm}$ suppressed the inward current. The current reappeared when the concentration of $\mathrm{Ca}^{2+}$ was increased to control levels of $2 \mathrm{~mm}$.

\section{Kinetics of the LTT Ca ${ }^{2+}$ current}

The voltage dependence of steady state inactivation and activation of the LTT $\mathrm{Ca}^{2+}$ current is shown in Figure 4. Steady state inactivation was measured by varying the holding potential pulse from -120 to $-45 \mathrm{mV}$ and activating peak current with a command potential to $-30 \mathrm{mV}$. Steady state inactivation was observed when the holding potential was positive to $-100 \mathrm{mV}$. The current was half-inactivated at $-84 \mathrm{mV}$ and was totally inactivated at $-60 \mathrm{mV}$. The fractional current, normalized to the maximum current, was smoothly voltage dependent and was fit with the following Boltzmann equation:

$$
I / I_{\max }=\left\{1+\exp \left[\left(V-V_{0.5}\right) / k\right]\right\}^{-1},
$$

where $I$ is peak current at $V, I_{\max }$ is the maximum current from a holding potential of $-100 \mathrm{mV}, V$ is the holding potential, $V_{0.5}$ is the half-inactivation value, and $k$ is the steepness factor. The curve was best fit when $V_{0.5}=-84.3 \mathrm{mV}$ and $k=6.3$. The voltage dependence of activation of the LTT Ca ${ }^{2+}$ current was examined by varying command potential pulses from a constant holding potential of $-120 \mathrm{mV}$. The current was half-activated at $-47 \mathrm{mV}$. The curve was smoothly voltage dependent and was fit by the Boltzmann function

$$
I / I_{\max }=\left\{1+\exp \left[-\left(V-V_{0.5}\right) / k\right]\right\}^{-1} .
$$


A

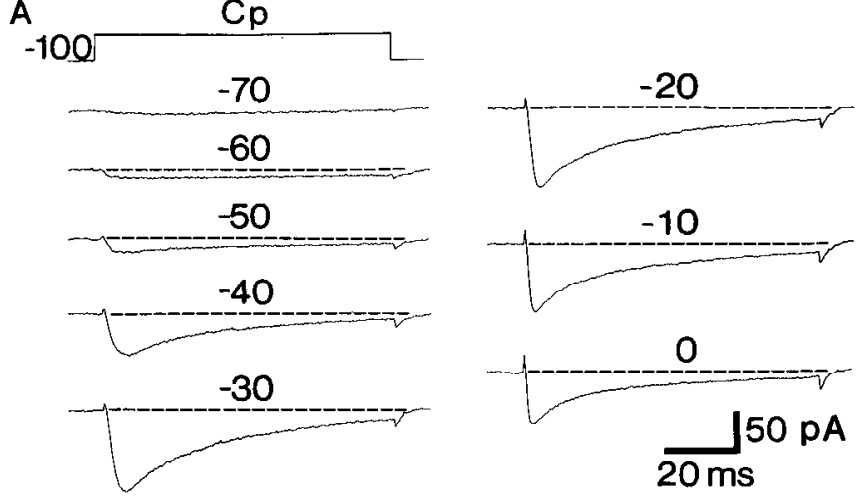

B

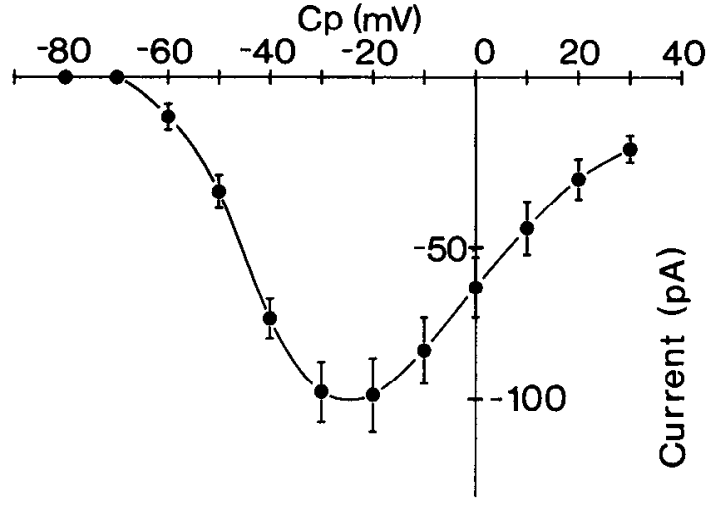

Figure 2. LTT $\mathrm{Ca}^{2+}$ currents recorded in an acutely dissociated L-M interneuron. $A$, Whole-cell voltage clamping revealed the LTT $\mathrm{Ca}^{2+}$ current when the cell was clamped at a holding potential of $-100 \mathrm{mV}$. Averaged currents $(n=4)$ are illusirated. Command potentials $(C p)$ more positive than $-70 \mathrm{mV}$ activated the LTT $\mathrm{Ca}^{2+}$ current. Peak inward current was recorded at $-30 \mathrm{mV}$. The broken lines indicate 0 current. $B$, The $I / V$ relationship of the LTT $\mathrm{Ca}^{2+}$ current is plotted. Points of the plot are the mean \pm SEM $(n=15$ separate cells). Peak current of $100 \pm 9 \mathrm{pA}$ was recorded at $-30 \mathrm{mV}$.

The best fit of the curve was obtained when $V_{0.5}=-47.5 \mathrm{mV}$ and $k=5.5$.

The time-to-peak of the LTT $\mathrm{Ca}^{2+}$ current $\left(t_{p}\right)$ was voltage dependent, and it ranged from $10 \mathrm{msec}$ at $-60 \mathrm{mV}$ to $4 \mathrm{msec}$ at $0 \mathrm{mV}$ (Fig. 5). The rate constant of inactivation of the current $\left(\tau_{h}\right)$ was also voltage dependent and ranged from $27 \mathrm{msec}$ at $-60 \mathrm{mV}$ to approximately $12 \mathrm{msec}$ at $>-30 \mathrm{mV}$. The rate of inactivation of the LTT $\mathrm{Ca}^{2+}$ current was estimated using an iterative fitting program (CLAMPFI, Axon Inst.). In all cases the rate of inactivation was best fit by a single exponential $(R>$ $0.95)$, indicating that there was no contamination by other $\mathrm{Ca}^{2+}$ current subtypes under these conditions.

The recovery from inactivation was examined by repolarizing cells to $-100 \mathrm{mV}$ from a holding potential of $-60 \mathrm{mV}$ for various latencies before eliciting the inward current with a command pulse to $-30 \mathrm{mV}$ (Fig. 6). Recovery to $90 \%$ occurred within $200 \mathrm{msec}$. These properties are very similar to those reported for LTT $\mathrm{Ca}^{2+}$ currents in many other cell types.

The block of LTT $\mathrm{Ca}^{2+}$ currents by lanthanum and divalent cations in other cell types has a unique selectivity and occurs at lower concentrations of $\mathrm{Ni}^{2+}$ than of $\mathrm{Cd}^{2+}$. We did not find a similar differential sensitivity (Fig. 7). The relative potency of

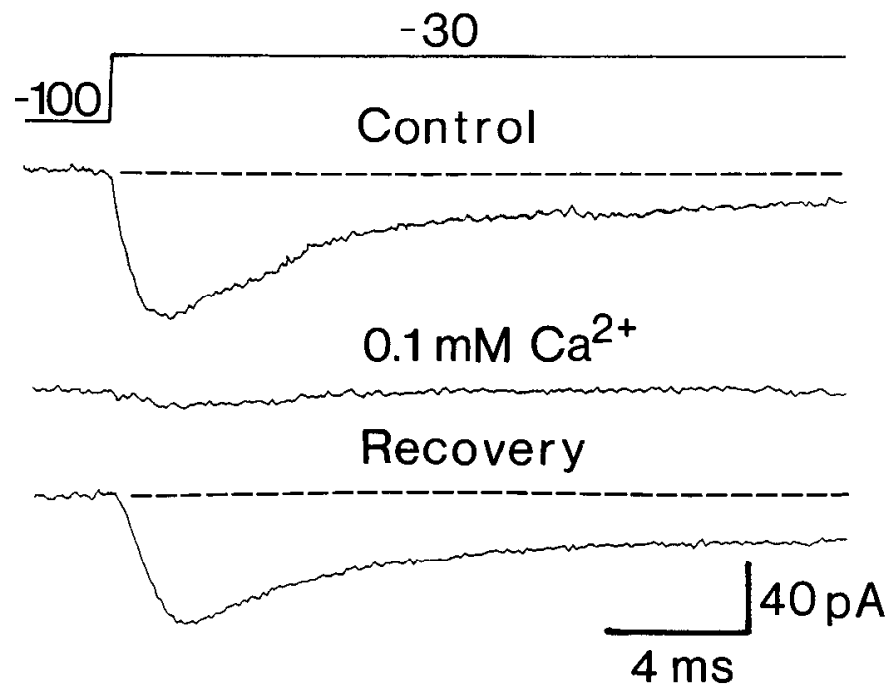

Figure 3. $\mathrm{Ca}^{2+}$ dependency of the LTT $\mathrm{Ca}^{2+}$ current. A voltage step to $-30 \mathrm{mV}$ from a holding potential of $-100 \mathrm{mV}$ activated the LTT Ca ${ }^{2+}$ current in control solution containing $2 \mathrm{mM} \mathrm{Ca}^{2+}$. When extracellular $\mathrm{Ca}^{2+}$ was reduced to $0.1 \mathrm{mM}$, the LTT $\mathrm{Ca}^{2+}$ was depressed but recovered when extracellular $\mathrm{Ca}^{2+}$ was returned to control levels of $2 \mathrm{~mm}$.

block was as follows: $\left(\mathrm{IC}_{50}\right.$ in $\mathrm{M}$; mean $\left.\pm \mathrm{SEM}\right): \mathrm{La}^{3+}(2.9 \pm 0.3$ $\left.\times 10^{-5} ; n=3\right) \gg \mathrm{Zn}^{2+}\left(1.5 \pm 0.12 \times 10^{-4} ; n=3\right)>\mathrm{Cd}^{2+}(2.6$ $\left.\pm 0.20 \times 10^{-4} ; n=5\right)>\mathrm{Ni}^{2+}\left(4.0 \pm 0.31 \times 10^{-4} ; n=5\right)>$ $\mathrm{Co}^{++}\left(7.6 \pm 0.30 \times 10^{-4} ; n=3\right)$. The depression at each concentration was observed after a 2 min application. It is interesting to note that in this time frame $\mathrm{Cd}^{2+}$ is more potent at blocking the LTT $\mathrm{Ca}^{2+}$ current than is $\mathrm{Ni}^{2+}$. This has also been observed in cells from the hypothalamus (Akaike et al., 1989).

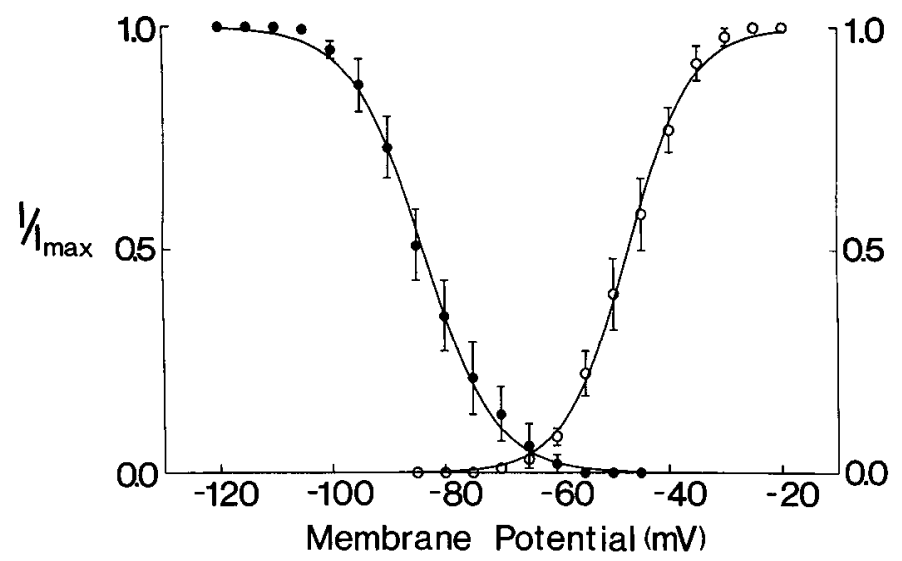

Figure 4. Voltage dependency of inactivation and activation of the LTT $\mathrm{Ca}^{2+}$ current. The inactivation curve [left curve $\left.(\odot)\right]$ was analyzed by a changing holding potential from -120 to $-45 \mathrm{mV}$ and evoking peak current by a command potential to $-30 \mathrm{mV}$. The points plotted are mean \pm SEM from measurements in four different cells. The points were fit by a Boltzmann equation as described in Results. The voltage at which half-maximal inactivation occurred was $-84 \mathrm{mV}$, and the steepness factor of the equation $(k)$ was 6.3 . The voltage dependency of activation [right curve (O)] was analyzed by stepping to command potentials from -85 to $-15 \mathrm{mV}$ from a holding potential of $-120 \mathrm{mV}$. The points plotted are mean \pm SEM from five different cells. The data points were fit by the Boltzmann relation as described in Results. The voltage at which half-maximal activation occurred was $-47 \mathrm{mV}$, and the steepness factor was 5.5 
A

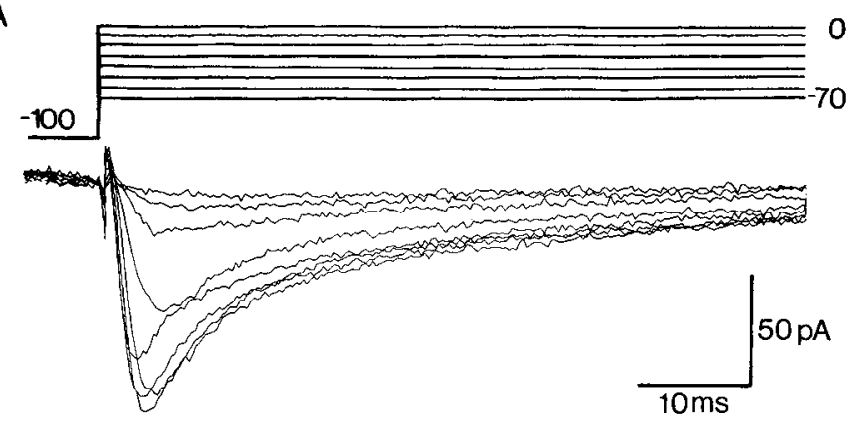

B
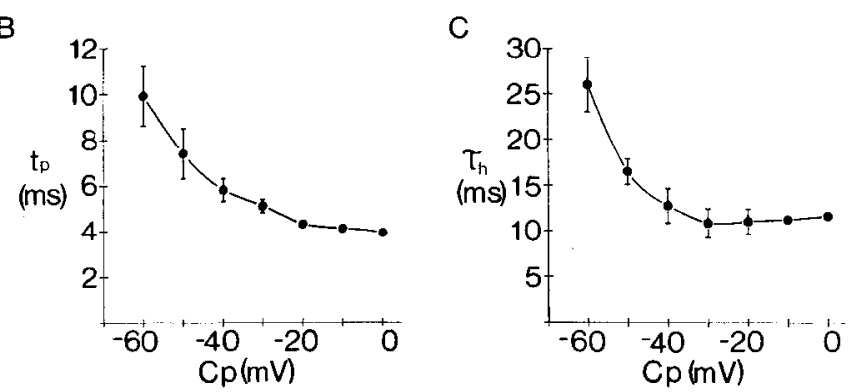

Figure 5. Voltage dependency of the time-to-peak and the rate of inactivation of the LTT $\mathrm{Ca}^{2+}$ current. $A$, The LTT Ca ${ }^{2+}$ current evoked from the holding potential of $-100 \mathrm{mV}$ to command potentials of between -60 and $0 \mathrm{mV}$ are illustrated. Each trace represents the average current from three trials. $B$, The time-to-peak $\left(t_{n}\right)$ of the LTT $\mathrm{Ca}^{2+}$ current is plotted as a function of command potential $(C p)$ voltage. The LTT $\mathrm{Ca}^{2+}$ current decreased from $10 \mathrm{msec}$ at $-60 \mathrm{mV}$ to $4 \mathrm{msec}$ at 0 $\mathrm{mV}$. $C$, The rate of inactivation of the LTT $\mathrm{Ca}^{2+}$ current was fit using an iterative fitting program (CLAMPFIT, Axon Instruments). Inactivation of all LTT $\mathrm{Ca}^{2+}$ currents analyzed was best fit by a single exponential. The time constant of inactivation $\left(t_{h}\right)$ was voltage dependent and ranged from $27 \mathrm{msec}$ at $-60 \mathrm{mV}$ to $12 \mathrm{msec}$ at $-30 \mathrm{mV}$. The rate of inactivation did not decrease with further depolarization past $-30 \mathrm{mV}$. The observation that LTT $\mathrm{Ca}^{2+}$ currents inactivated with a single exponential suggests that there was no contamination by other $\mathrm{Ca}^{2+}$ current subtypes under these conditions. Each point in $B$ and $C$ represents mean \pm SEM from measurements in five different cells.

\section{Modulation by neurotransmitters}

Application of $\mathrm{CCH}$ or 5-HT enhanced the amplitude of the LTT $\mathrm{Ca}^{2+}$ current. $\mathrm{CCH}(50 \mu \mathrm{M})$ increased the peak amplitude of the LTT $\mathrm{Ca}^{2+}$ current by $54 \pm 8 \%$ (mean $\pm \mathrm{SEM} ; n=18$ out of 22 cells; Fig. 8). Neither the activation threshold nor holding current was altered. Desensitization of the response to $\mathrm{CCH}$ did not occur in the time course of the experiments (within a few minutes). The enhancement of the current by $\mathrm{CCH}$ was rapidly reversed following washout and could be evoked repetitively with reapplication of the drug. The enhancement of the L'T'T Ca ${ }^{2+}$ current by carbachol was blocked by atropine $(1 \mu \mathrm{M}$; $n=9$ ). Therefore, the response appears to be mediated by muscarinic receptors. We did not further differentiate between muscarinic receptor subtypes.

5-HT ( $30 \mu \mathrm{M})$ increased the LTT $\mathrm{Ca}^{2+}$ current by $61 \pm 11 \%$ (mean \pm SEM; $n=19$ out of 22 cells; Fig. 9) without affecting holding current. However, in the presence of 5-HT, the peak current was often observed at a more negative potential. The enhancement of the peak LTT $\mathrm{Ca}^{2+}$ current occurred rapidly after application of 5-HT, and there was no evidence for de-

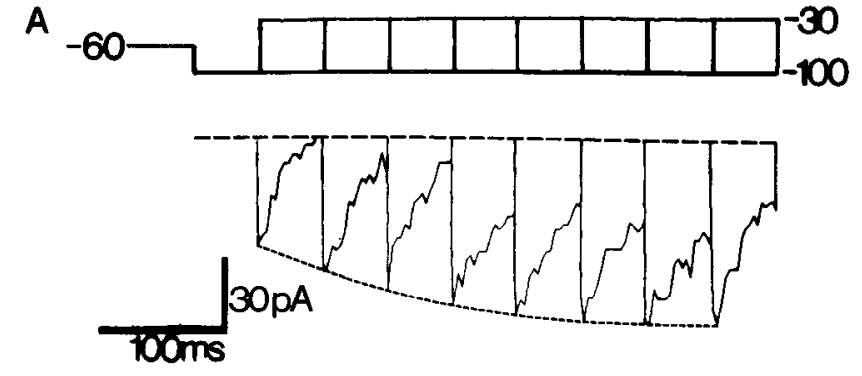

B
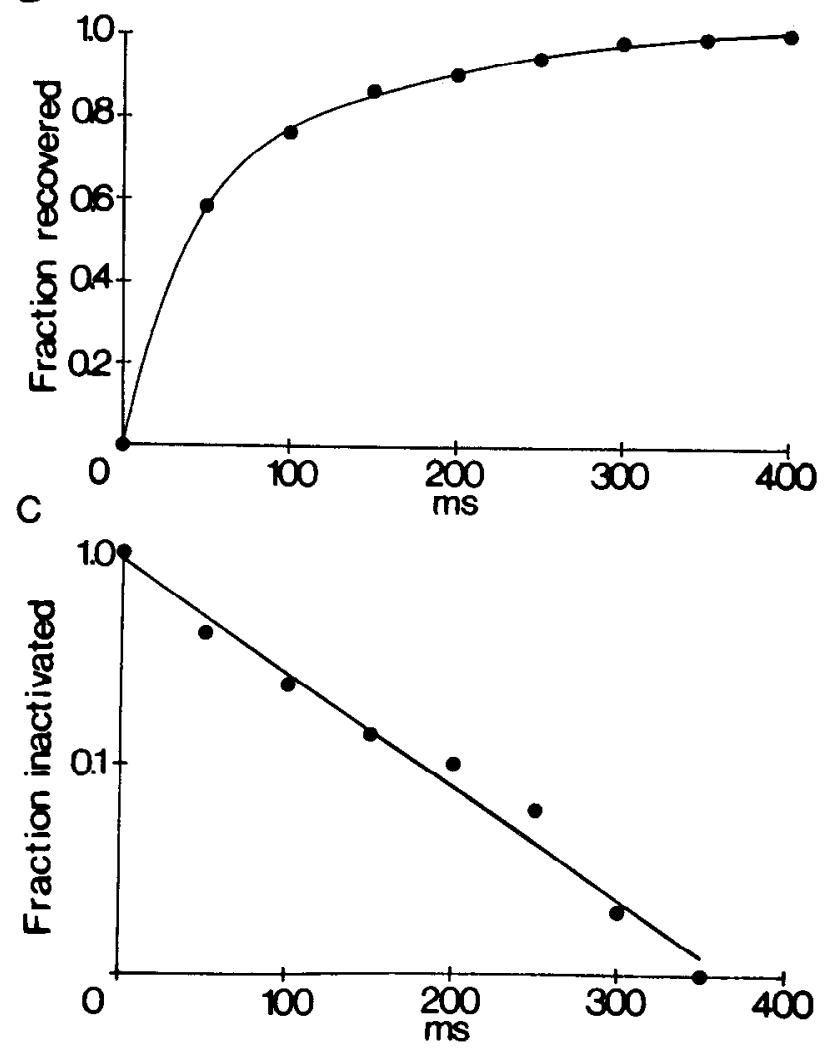

Figure 6. Time course of the recovery from inactivation of the LTT $\mathrm{Ca}^{2+}$ current. $A$, Holding potential was stepped from -60 to $-100 \mathrm{mV}$ for various latencies before the LTT $\mathrm{Ca}^{2+}$ current was evoked by a command potential to $-30 \mathrm{mV}$. The fractional depression of the LTT $\mathrm{Ca}^{2+}$ current was plotted with respect to the maximum LTT Ca ${ }^{2+}$ current that was evoked from a holding potential of $-100 \mathrm{mV}$ that had been maintained for at least $10 \mathrm{sec}$. The fractional recovery of the $\mathrm{Ca}^{2+}$ current is plotted as a function of time in $B$, and the fraction inactivated is plotted as a function of time in $C$. It can be seen that approximately $90 \%$ of the current has recovered within an interval of $200 \mathrm{msec}$.

sensitization during application for several minutes. The action of 5-HT was quickly reversible following washout and could be evoked repetitively with reapplication of the drug. Co-application of spiperone ( $1 \mu \mathrm{M} ; n=7)$, a serotonergic antagonist, totally blocked the 5-HT-induced enhancement of the LTT Ca ${ }^{2+}$ current.

Synaptic inputs from the septum onto L-M interneurons have also been shown to contain GABA (Freund and Antal, 1988). We examined the action of baclofen, $\mathrm{a} \mathrm{GABA}_{\mathrm{B}}$ agonist, on the LTT $\mathrm{Ca}^{2+}$ current. Baclofen $(20 \mu \mathrm{M})$ reversibly depressed the magnitude of the LTT $\mathrm{Ca}^{2+}$ current by $53 \pm 16 \%$ (mean \pm SEM; $n=5$ out of 7 cells; Fig. 10). 


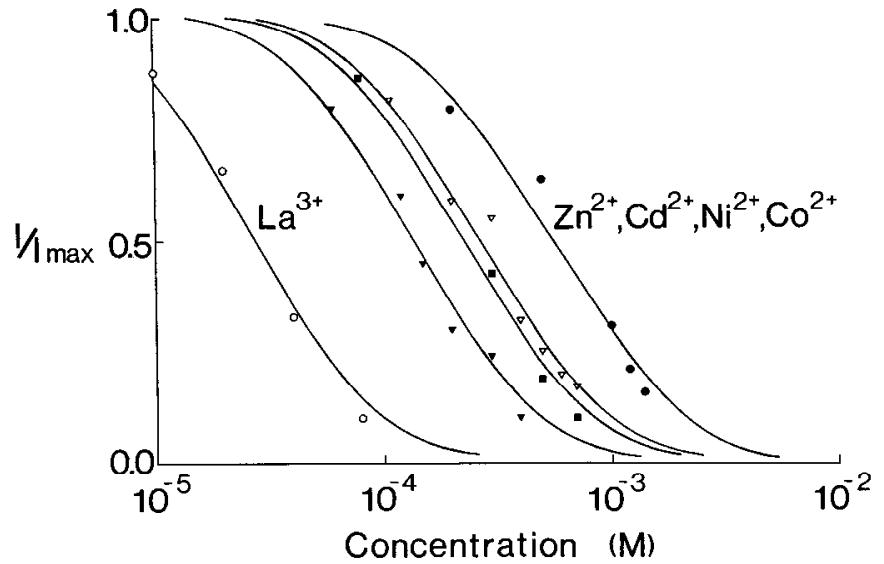

Figure 7. Block of the LTT Ca ${ }^{2+}$ current by lanthanum and divalent cations $\left[\mathrm{La}^{3+}(0), \mathrm{Zn}^{2+}(\nabla), \mathrm{Cd}^{2+}(\square), \mathrm{Ni}^{2+}(\nabla)\right.$, and $\left.\mathrm{Co}^{2+}(\bullet)\right]$. The fractional depression of the LTT $\mathrm{Ca}^{2+}$ current plotted as a function of the different concentrations of the indicated ions. The peak currents were evoked by command potentials to $-25 \mathrm{mV}$ from a holding potential of $-100 \mathrm{mV}$. The points plotted for each ion are representative of individual experiments.

\section{Discussion}

In a previous study, Lacaille and Schwartzkroin (1988a) suggested that L-M interneurons might have low-threshold $\mathrm{Ca}^{2+}$ spikes. They reported that when the cells were hyperpolarized the firing response to a depolarizing current pulse changed from steady tonic firing to phasic burst firing. Interneurons in the oriens-alveus or pyramidal layer do not exhibit this transition in firing pattern (Lacaille and Williams, 1990). The present study on acutely dissociated L-M interneurons confirms that these cells do indeed have an LTT $\mathrm{Ca}^{2+}$ current, which could underlie a low-threshold $\mathrm{Ca}^{2+}$ spike. This current fit the criteria for a t-type $\mathrm{Ca}^{2+}$ current because (1) it was transient and activated at a low threshold, (2) it was insensitive to TTX but was $\mathrm{Ca}^{2+}$ dependent, (3) it was totally inactivated at $-60 \mathrm{mV}$ holding potential, and (4) it displayed metabolic stability in that it did not "run down" significantly in the time course of these experiments.

Analysis of the kinetic properties of the LTT $\mathrm{Ca}^{2+}$ current in L-M interneurons indicates many similarities to this type of $\mathrm{Ca}^{2+}$ current in other cells (e.g., Carbone and Lux, 1984b; Ryu and Randic, 1990) but also somie important differences. A major difference is that the time-to-peak and the rate of inactivation are faster in the present study. For example, the time-to-peak and time constant of inactivation over a range of potentials have been reported to be $>7 \mathrm{msec}$ and $>20 \mathrm{msec}$, respectively, in LGN neurons (Hernandez-Cruz and Pape, 1989) and >10 mscc and $>40 \mathrm{msec}$, respectively, in hypothalamic neurons (Akaike et al., 1989). However, the concentration of external $\mathrm{Ca}^{2+}$ in these studies was 5 and $10 \mathrm{~mm}$, whereas the currents in the present study were recorded in $2 \mathrm{mM} \mathrm{Ca}^{2+}$, which is much closer to the extracellular concentration in vivo. Increasing the concentration of extracellular $\mathrm{Ca}^{2+}$ alters the voltage sensitivity of most currents by charge screening effects and also slows the activation and inactivation kinetics for $\mathrm{Ca}^{2+}$ currents (Ohmori and Yoshii, 1977; Wilson et al., 1983). Although we did not examine the time constants in different $\mathrm{Ca}^{2+}$ concentrations, this does seem to be a reasonable explanation for the differences.

The kinetic analysis also gives some clues as to the effect that this current might have on L-M interneuron firing pattern. These cells have a resting potential of approximately $-60 \mathrm{mV}$ (Lacaille and Schwartzkroin, 1988a), which would inactivate the LTT $\mathrm{Ca}^{2+}$ current. Hyperpolarization that lasted $>50 \mathrm{msec}$ would cause significant deinactivation $(>60 \%)$ of the current so that a low-threshold $\mathrm{Ca}^{2+}$ spike may fire as rebound excitation. This pattern has been reported in the inferior olive (Llinas and Yarom, 1981) and the thalamus (Jahnsen and Llinas, 1984a).
A

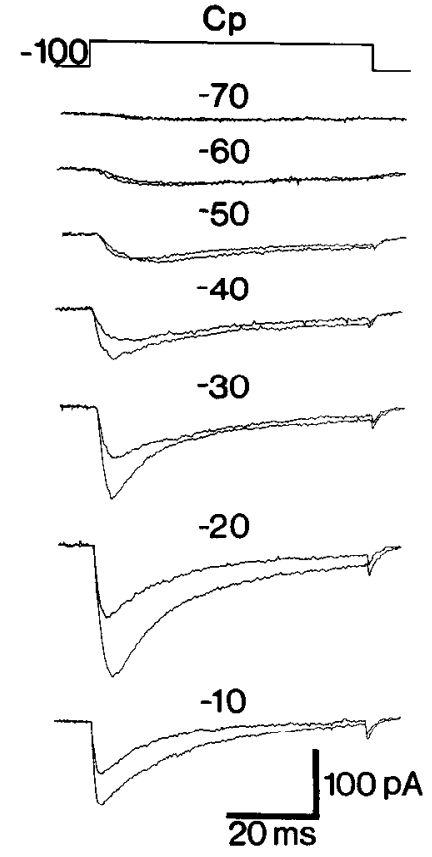

B

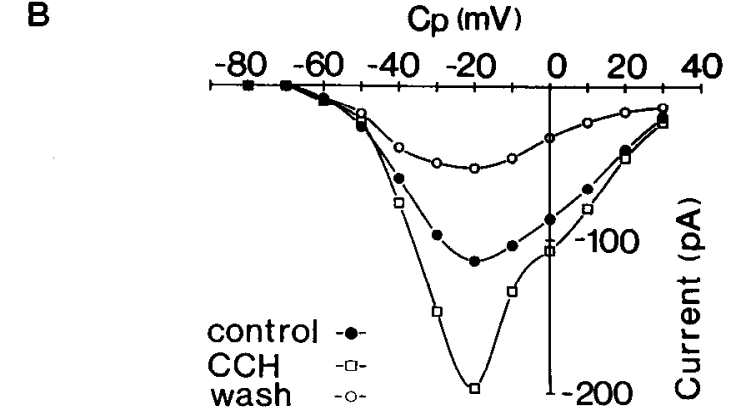

C

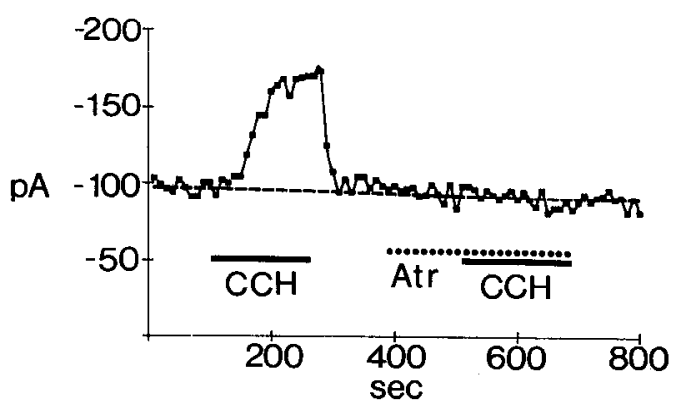

Figure 8. Enhancement of the LTT $\mathrm{Ca}^{2+}$ current by muscarinic stimulation. $A$, Illustrated LTT $\mathrm{Ca}^{2+}$ currents were evoked from a holding potentiai of $-100 \mathrm{mV}$ to the indicated command potentials $(C p)$. The smaller-amplitude currents at each potential are the control currents, and the enhanced currents are those recorded in $C C H(50 \mu \mathrm{M}) . B$, The $I / V$ relationship of the LTT $\mathrm{Ca}^{2+}$ current (same cell as $A$ ) is illustrated showing the enhancement in the amplitude but no shift in the $I / V$ relationship induced by $\mathrm{CCH}$. The enhancement of the current in $\mathrm{CCH}$ was reversible upon washout. $C$, The peak inward current elicited by a command potential of $-25 \mathrm{mV}$ from a holding potential of $-100 \mathrm{mV}$ is plotted as a function of time. Perfusion of $\mathrm{CCH}$ ( 50 $\mu \mathrm{M})$ quickly and reversibly enhanced the amplitude of the current from 100 to $175 \mathrm{pA}$. However, in the presence of atropine $(A t r ; 1 \mu \mathrm{M}), \mathrm{CCH}$ had no effect. This indicates that $\mathrm{CCH}$ was acting on a muscarinic receptor. 
Figure 9. Enhancement of the LTT $\mathrm{Ca}^{2+}$ current by 5-HT. $A$, The LTT Ca ${ }^{2+}$ currents evoked from a holding potential of $-100 \mathrm{mV}$ to the indicated command potentials $(C p)$ are illustrated. The lower-amplitude currents at all potentials were recorded in control solution. The higher-amplitude currents were recorded after the perfusion of 5-HT $(30$ $\mu$ M). $B, I / V$ plot of the LTT $\mathrm{Ca}^{2+}$ currents in control and 5-HT (same cell as in $A$ ). Perfusion of 5-HT enhanced the amplitude of the LTT $\mathrm{Ca}^{2+}$ current. This effect was reversible upon wash of the 5-HT. C, Peak $\mathrm{Ca}^{2+}$ currents were evoked by stepping to $-25 \mathrm{mV}$ from a holding potential of $-100 \mathrm{mV}$. Peak $\mathrm{Ca}^{2+}$ current was enhanced from 100 to $155 \mathrm{pA}$ when 5 -HT was perfused. This effect was reversible. However, when spiperone (Spip; $1 \mu \mathrm{M})$ was perfused, 5-HT had no effect.
A

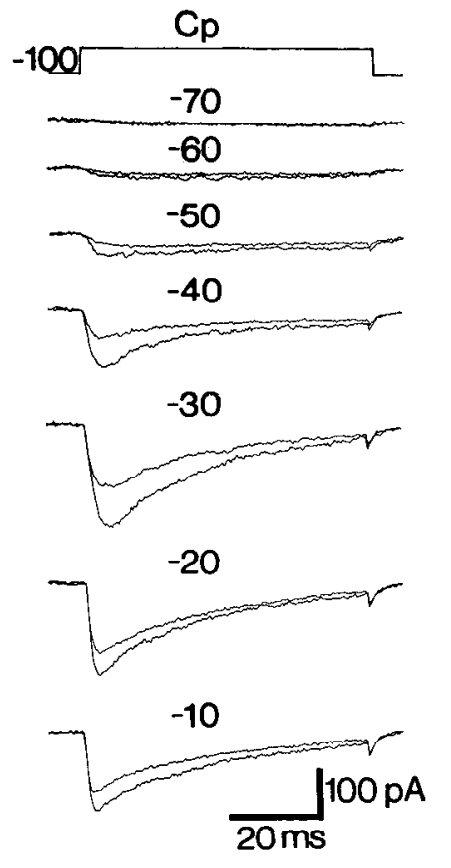

B
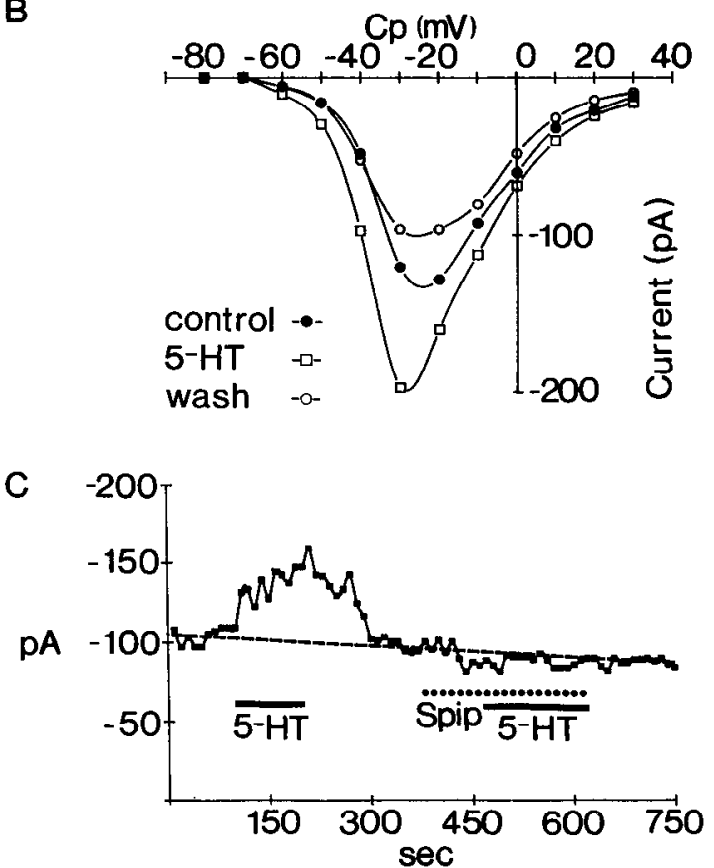

The LTT $\mathrm{Ca}^{2+}$ current has been shown to be stable in the presence of intracellular $\mathrm{F}^{-}$in several cell types (HernandezCruz and Pape, 1989; Takahashi et al., 1989), so it was not surprising that the LTT $\mathrm{Ca}^{2+}$ current in L-M interneurons was also stable when the pipette contained $\mathrm{F}^{-}$. What is surprising is that modulation of the LTT Ca ${ }^{2+}$ current could still be observed. GTP-binding proteins, which mediate signal transduction by interacting with receptor proteins, are activated by $\mathrm{F}^{-}$in the presence of $\mathrm{Al}^{3+}$ (Sternweis and Gilman, 1982; Bigay et al., 1985). The activation of GTP-binding proteins results from the binding of $\mathrm{AIF}_{4}{ }^{-}$to the nucleotide site of $\mathrm{G}_{\alpha}$, next to the $\beta$-phosphate of GDP, mimicking the GTP $\gamma$-phosphate (Kanaho et al., 1985; Bigay et al., 1987). The dissociation of $\mathrm{G}_{\alpha}$ from $\beta \gamma$ is thereby enhanced. Nevertheless, modulation of the LTT $\mathrm{Ca}^{2+}$ current by neurotransmitters was reversible following washout and reproducible with reapplication of the drug. These two observations suggest that maximal activation of GTP-binding proteins, under our conditions, did not occur.

L-M interneurons are believed to be inhibitory because (1) they stain positive for glutamic acid decarboxylase (Ribak et al., 1978; Kosaka et al., 1985), the enzyme indicative of GABAergic neurons, (2) they form symmetrical synapses upon hippocampal dendrites indicative of inhibitory synapses (Kunkel et al., 1988), and (3) simultaneous intracellular recordings between L-M interneurons and pyramidal cells have provided some indication of inhibition (Lacaille and Schwartzkroin, 1988b). The presence of low-threshold $\mathrm{Ca}^{2+}$ spikes and LTT $\mathrm{Ca}^{2+}$ currents in L-M interneurons could have significant implications concerning the generation of different firing patterns in hippocampal pyramidal neurons. Low-threshold $\mathrm{Ca}^{2+}$ spikes result in rhythmic bursting in neurons in the thalmus (Deschenes et al., 1984; Jahnsen and Llinas, 1984a,b) and the lateral habenula (Wilcox et al., 1988) at approximately $10 \mathrm{~Hz}$, which is the theta frequency in the hippocampus. L-M interneurons normally fire action potentials at a slow, steady rate (Kawaguchi and Hama, 1987). Enhancement of the LTT $\mathrm{Ca}^{2+}$ current and membrane hyperpolarization could cause L-M cells to shift from tonic firing into a repetitive bursting mode. It is possible that burst firing in L-M interneurons could alter the strength of inhibition on pyramidal cells from a steady tonic level to rhythmically varying. Thus, membrane potential oscillations in L-M interneurons could cause rhythmic activity in hippocampal pyramidal cells.

Cholinergic and GABAergic inputs to the hippocampus arise from the medial septum (Storm-Mathisen, 1977), some of which have been shown to synapse directly upon L-M interneurons (Freund and Antal, 1988). Serotonergic inputs to the hippocampus arise from the raphe nuclei, and their innervation has been shown to be particularly dense in the L-M region (Storm-Mathisen, 1977). A recent study, utilizing electron microscopy, has also shown that serotonergic inputs from the raphe make synaptic connections with L-M interneurons (Freund et al., 1990). Both the cholinergic-septal and the serotonergic-raphe pathways are believed to be involved in generating type 1 and type 2 theta rhythm in the hippocampus (Bland, 1986; Vanderwolf and Baker, 1986). Generation of cholinergic-induced theta rhythm in the hippocampus does not appear to depend upon rhythmic synaptic inputs from structures outside the hippocampus because perfusion of carbachol on isolated brain slices can induce theta rhythm (Konopacki et al., 1987; MacVicar and Tse, 1989). It appears, therefore, that synaptic circuitry and intrinsic membrane conductances sufficient for generating theta are intrinsic to the hippocampus. The synaptic effects of cholinergic and serotonergic inputs on hippocampal pyramidal neurons are quite different (reviewed in Nicoll, 1988). Cholinergic inputs depress high-threshold $\mathrm{Ca}^{2+}$ currents and depolarize pyramidal cells by blocking the M-current. Serotonergic inputs hyperpolarize pyramidal neurons by increasing potassium conductance. Serotonin has also been reported to enhance $\mathrm{Ca}^{2+}$ spikes in the substantia nigra (Nedergaard et al., 1988) and to enhance LTT $\mathrm{Ca}^{2+}$ currents in rat spinal motoneurons (Berger and Takahashi, 1990). However, both transmitter systems ap- 
A

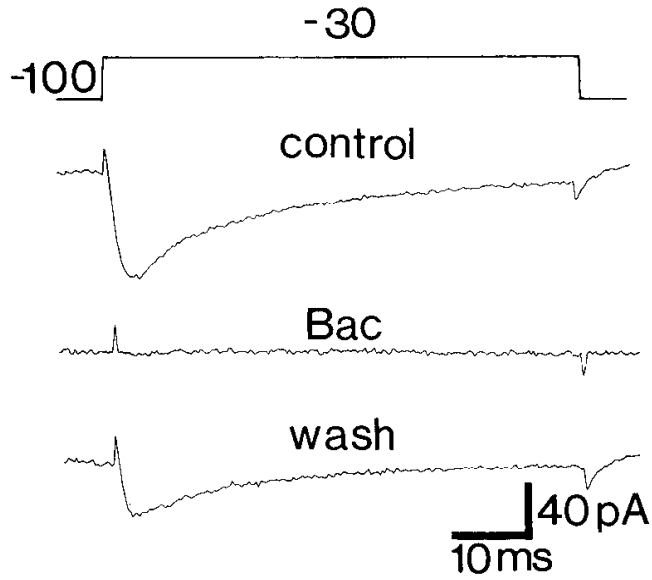

B

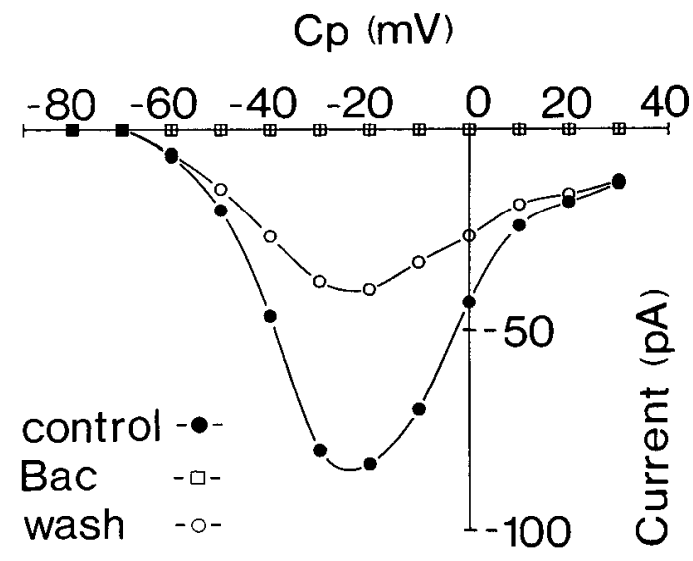

Figure 10. Baclofen depressed the I.TT Ca ${ }^{2+}$ current. $A$, Peak inward $\mathrm{Ca}^{2+}$ current was evoked by stepping to $-30 \mathrm{mV}$ from a holding potential of $-100 \mathrm{mV}$. The LTT $\mathrm{Ca}^{2+}$ current was depressed in the presence of baclofen $(B a c ; 20 \mu \mathrm{M})$. This effect was reversible upon washout. $B$, The $I / V$ relationship of the LTT $\mathrm{Ca}^{2+}$ current and the effect of baclofen are illustrated. Baclofen totally depressed the LTT Ca ${ }^{2+}$ current, and this effect was reversible upon washout.

pear to have a common effect on L-M interneurons of increasing LTT $\mathrm{Ca}^{2+}$ currents. It has previously been suggested that the septal pacemaker drives hippocampal theta by rhythmically activating interneurons (Buzsaki et al., 1983; Stewart and Fox, 1990). Interneurons have also been reported to be theta cells and fire at theta frequencies during behaviorally evoked theta (reviewed in Buzsaki et al., 1983; Fox et al., 1986). Our work suggests an alternative hypothesis: that cholinergic and serotonergic inputs may enhance LTT $\mathrm{Ca}^{2+}$ currents, which could trigger endogenous oscillation of L-M interneurons and thereby induce hippocampal theta. GABAergic input may play a role in terminating theta by depressing the LTT $\mathrm{Ca}^{2+}$ current.

In the $\mathrm{CA} 3$ region of isolated slices, we have shown that the CCH-induced theta rhythm is not affected by $\mathrm{GABA}_{A}$ or $\mathrm{GABA}_{B}$ antagonists but is blocked by kynurenic acid, a wide-spectrum excitatory amino acid antagonist (MacVicar and Tse, 1989). In the CA3 region, therefore, EPSPs underlie theta activity, possibly through glutamatergic input to pyramidal neurons. If L-M interneurons generate theta in the CA1 region, one would expect a much more prominent role for inhibitory circuits in generating theta in the slice. It is possible that there are multiple cellular components that generate theta that can all oscillate at $10 \mathrm{~Hz}$. Synchronization could be due to both recurrent excitatory and inhibitory circuits.

\section{References}

Akaike N, Kostyuk PG, Osipchuk YV (1989) Dihydropyridine-sensitive low threshold-calcium channels in isolated rat hypothalamic neurones. J Physiol (Lond) 412:181-195.

Alvarez De Toledo GA, Lopez-Barneo J (1988) Ionic basis of the differential neuronal activity of guinea-pig septal nucleus studied in vitro. J Physiol (Lond) 396:399-415.

Berger AJ, Takahashi T (1990) Serotonin enhances a low-voltageactivated calcium current in rat spinal motoneurons. J Neurosci 10 : 1922-1928.

Bigay J, Deterre P, Pfister C, Chabre M (1985) Fluoroaluminates activate transducin-GDP by mimicking the $\gamma$-phosphate of GTP in its binding side. FEBS Lett 191:181-85.

Bigay J, Deterre P, Pfister C, Chabre M (1987) Fluoride complexes of aluminum or beryllium act on G-proteins as reversibly bound analogues of the $\gamma$ phosphate of GTP. EMBO J. 6:2907-2913.
Bland BH (1986) The physiology and pharmacology of hippocampal formation theta rhythms. Prog Neurobiol 26:1-54.

Buzsaki G, Leung LS, Vanderwolf CH (1983) Cellular basis of hippocampal EEG in the behaving rat. Brain Res Rev 6:139-171.

Carbone E, Lux HD (1984a) A low voltage-activated, fully inactivating $\mathrm{Ca}$ channel in vertebrate sensory neurones. Nature 310:501-502.

Carbone E, Lux HD (1984b) A low voltage-activated calcium conductance in embryonic chick sensory neurons. Biophys J 46:413-418.

Coulter DA, Huguenard JR, Prince DA (1989) Calcium currents in rat thalamacortical relay neurones: kinetic properties of the transient, low-threshold current. J Physiol (Lond) 414:587-604.

Deschenes M, Paradis M, Roy JP, Steriade M (1984) Electrophysiology of neurons of lateral thalamic nuclei in cat: resting properties and burst discharges. J Neurophysiol 51:1196-1219.

Duffy S, Tse FW, Hochman D, Fraser DD, MacVicar BA (1991) Voltage-activated $\mathrm{K}^{+}$and $\mathrm{Ca}^{++}$channels in acutely isolated hippocampal astrocytes. Soc Neurosci Abstr 16:666.

Fisher RE, Gray R, Johnston D (1990) Properties and distribution of single voltage-gated calcium channels in adult hippocampal neurons. J Neurophysiol 64:91-104.

Fox SE, Wolfson S, Ranck JB Jr (1986) Hippocampal theta rhythm and the firing of neurons in walking and urethane-anesthetized rats. Exp Brain Res 62:495-508.

Fox AP, Nowycky MC, Tsien RW (1987a) Kinetic and pharmacological properties distinguishing three types of calcium currents in chick sensory neurones. J Physiol (Lond) 394:149-172.

Fox AP, Nowycky MC, Tsien RW (1987b) Single-channel recordings of three types of calcium channels in chick sensory neurones. J Physiol (Lond) 394:173-200.

Fraser DD, MacVicar BA (1990) Low threshold transient $\mathrm{Ca}^{2+}$ currents in acutely dissociated hippocampal lacunosum-moleculare interneurons. Soc Neurosci Abstr 16:676.

Freund TF, Antal M (1988) GABA-containing neurons in the septum control inhibitory interneurons in the hippocampus. Nature 336:170173.

Freund TF, Gulyas AI, Acsady L, Gorcs T, Toth K (1990) Serotonergic control of the hippocampus via local inhibitory interneurons. Proc Natl Acad Sci USA 87:8501-8505.

Friedman A, Gutnick MJ (1987) Low-threshold calcium clectrogencsis in neocortical neurons. Neurosci Lett 81:117-122.

Hernandez-Cruz A, Pape HC (1989) Identification of two calcium currents in acutely dissociated neurons from the rat lateral geniculate nucleus. J Neurophysiol 61:1270-1283.

Jahnsen H, Llinas R (1984a) Electrophysiological properties of guineapig thalamic neurones: an in vitro study. J Physiol (Lond) 349:205226.

Jahnsen H, Llinas R (1984b) Ionic basis for the electroresponsiveness and oscillatory properties of guinea-pig thalamic neurones in vitro. J Physiol (Lond) 349:227-247. 
Kanaho Y, Moss J, Vaughan M (1985) Mechanism of inhibition of transducin GTPase activity by fluoride and aluminum. J Biol Chem 260:11493-11497.

Kawaguchi Y, Hama K (1987) Two subtypes of non-pyramidal cells in rat hippocampal formation identified by intracellular recording and HRP injection. Brain Res 411:190-195.

Kay AR, Wong RKS (1986) Isolation of neurons suitable for patchclamping from adult mammalian central nervous system. J Neurosci Methods 16:227-238.

Kay AR, Wong RKS (1987) Calcium current activation kinetics in isolated pyramidal neurones of the CAl region of the mature guineapig hippocampus. J Physiol (Lond) 392:603-616.

Kay AR, Miles R, Wong RKS (1986) Intracellular fluoride alters the kinetic properties of calcium currents facilitating the investigation of synaptic events in hippocampal neurons. J Neurosci 6:2915-2920.

Konopacki J, MacIver B, Bland BH, Roth SH (1987) Theta in hippocampal slices: relation to synaptic responses of dentate neurons. Brain Res Bull 18:25-27.

Kosaka T, Kosaka K, Tateishi K, Hamaoka Y, Yanaihara N, Wu JY, Hana K (1985) GABAergic neurons containing CCK-8-like and/or VIP-like immunoreactivities in the rat hippocampus and dentate gyrus. J Comp Neurol 239:420-430.

Kunkel DD, Lacaille J-C, Schwartzkroin PA (1988) Ultrastructure of stratum lacunosum-moleculare interneurons of hippocampal CAI region. Synapse 2:382-394.

Lacaille J-C, Schwartzkroin PA (1988a) Stratum lacunosum-moleculare interneurons of hippocampal CA I region: I. Intracellular response characteristics, synaptic response, and morphology. J Neurosci 8: 1632-1644.

Lacaille J-C, Schwartzkroin PA (1988b) Stratum lacunosum-moleculare interneurons of hippocampal CAl region: II. Intrasomatic and intradendritic recordings of local circuit synaptic interactions. J Neurosci 8:1645-1655.

Lacaille J-C, Williams S (1990) Membrane properties of interneurons in stratum orients-alveus of the CAl region of rat hippocampus in vitro. Neurosci 36:349-359.

Lacaille J-C, Kunkel DD, Schwartzkroin PA (1989) Electrophysiological and morphological characterization of hippocampal interneurons. In: The hippocampus - new vistas (Chan-Palay V, Kohler G, eds), pp 285-303. New York: Liss.

Llinas RR (1988) The intrinsic electrophysiological properties of mammalian neurons: insights into central nervous system function. Science 242:1654-1664.

Llinas R, Muhlethaler M (1988) Electrophysiology of guinea-pig cerebellar nuclear cells in the in vitro brain stem-cerebellar preparation. J Physiol (Lond) 404:241-258.

Llinas R, Yarom Y (1981) Electrophysiology of mammalian inferior olivary neurones in vitro. Different types of voltage-dependent ionic conductances. J Physiol (Lond) 315:549-567.

Llinas R, Yarom Y (1986) Oscillatory properties of guinea-pig inferior olivary neurones and their pharmacological modulation: an in vitro study. J Physiol (Lond) 376:163-182.

MacVicar BA, Tse FWY (1989) Local neuronal circuitry underlying cholinergic rhythmical slow activity in CA3 area of rat hippocampal slices. J Physiol (Lond) 417:197-212.

Misgeld U, Frotscher M (1986) Postsynaptic-GABAergic inhibition of non-pyramidal neurons in the guinea-pig hippocampus. Neuroscience 19:193-206.
Murase K, Randic M (1983) Electrophysiological properties of rat spinal dorsal horn neurons in vitro: calcium-dependent action potentials. J Physiol (Lond) 334:141-153.

Nedergaard S, Bolam JP, Greenfield SA (1988) Facilitation of a dendritic calcium conductance by 5-hydroxytryptamine in the substantia nigra. Nature 333:174-177.

Nicoll RA (1988) The coupling of neurotransmitter receptors to ion channels in the brain. Science 241:545-551.

Nowycky MC, Fox AP, Tsien RW (1985) Three types of neuronal calcium channel with different calcium agonist sensitivity. Nature 316:440-449.

Ohmori A, Yoshii M (1977) Surface potential reflected in both gating and permeation mechanisms of sodium and calcium channels of the tunicate egg cell membrane. J Physiol (Lond) 267:429-463.

Ozawa S, Tsuzuki K, lino M, Ogura A, Kado Y (1989) Three types of voltage-dependent calcium current in cultured rat hippocampal neurons. Brain Res 495:329-336.

Ribak CE, Vaughn JE, Saito K (1978) Immunocytochemical localization of glutamic acid decarboxylase in neuronal somata following colchicine inhibition of axonal transport. Brain Res 140:315-332.

Ryu PD, Randic M (1990) Low- and high-voltage-activated calcium currents in rat spinal dorsal horn neurons. J Neurophysiol 63:273285.

Sternweis PC, Gilman AG (1982) Aluminum: a requirement for activation of the regulatory component of adenylate cyclase by fluoride. Proc Natl Acad Sci USA 79:4888-4891.

Stewart M, Fox SE (1990) Do septal neurons pace the hippocampal theta rhythm? Trends Neurosci 13:163-168.

Storm-Mathisen J (1977) Localization of transmitter candidates in the brain: the hippocampal formation as a model. Prog Neurobiol 8:119181 .

Suzuki S, Rogawski MA (1989) T-type calcium channels mediate the transition between tonic and phasic firing in thalamic neurons. Proc Natl Acad Sci USA 86:7228-7232.

Takahashi K, Wakamori M, Akaike N (1989) Hippocampal CA1 pyramidal cells of rats have four voltage-dependent calcium conductances. Neurosci Lett 104:229-234.

I'se FWY, MacVicar BA (1989) Phosphoinositides and GI'P-binding proteins involved in muscarinic generation of hippocampal thythmic slow activity. Neurosci Lett 102:58-63.

Vanderwolf $\mathrm{CH}$, Baker GB (1986) Evidence that serotonin mediates non-cholinergic neocortical low voltage fast activity, non-cholinergic hippocampal rhythmical slow activity and contributes to intelligent behaviour. Brain Res 374:342-356.

Wilcox KS, Gutnick MJ, Christoph GR (1988) Electrophysiological properties of neurons in the lateral habenula nucleus: an in vitro study. J Neurophysiol 59:212-225.

Williams PJ, MacVicar BA, Pittman QJ (1990) Electrophysiological properties of neuroendocrine cells of the intact rat pars intermedia: multiple calcium currents. J Neurosci 10:748-756.

Wilson DL, Morimoto K, Tsuda Y, Brown AM (1983) Interaction between calcium ions and surface charge as it relates to calcium currents. J Membr Biol 72:117-130.

Yaari Y, Hamon B, Lux HD (1987) Development of two types of calcium channels in cultured mammalian hippocampal neurons. Science 235:680-682. 